\title{
Cold War Politics in Postwar Germany
}

David F. Patton 


\section{To my parents}

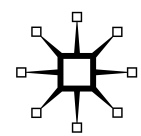

COLD WAR POLITICS IN POSTWAR GERMANY

Copyright (C) David F. Patton, 1999. All rights reserved. No part of this book may be used or reproduced in any manner whatsoever without written permission except in the case of brief quotations embodied in critical articles or reviews.

Softcover reprint of the hardcover 1st edition 1999 978-0-333-76527-2

First published in hardcover in 1999 by St. Martin's Press

First PALGRAVE ${ }^{\mathrm{TM}}$ edition: May 2001

175 Fifth Avenue, New York, N.Y. 10010 and

Houndmills, Basingstoke, Hampshire, England RG21 6XS

Companies and representatives throughout the world.

PALGRAVE is the new global publishing imprint of St. Martin's Press LLC Scholarly and Reference Division and Palgrave Publishers Ltd (formerly Macmillan Press Ltd).

\section{ISBN 978-1-349-41499-4}

ISBN 978-0-312-29961-3 (eBook)

\section{Library of Congress Cataloging-in-Publication Data}

Patton, David F., 1963-

Cold War politics in postwar Germany / David F. Patton.

p. $\mathrm{cm}$.

Includes bibliographical references and index.

\section{ISBN 978-1-349-41499-4}

1. Germany-Foreign relations - 1945- 2. World politics-1945-

I. Title.

DD257.4.P32 1999

327.43'009'045-dc21

A catalogue record for this book is available from the British Library.

Design by Letra Libre, Inc.

First paperback edition: May 2001

$\begin{array}{llllllllll}10 & 9 & 8 & 7 & 6 & 5 & 4 & 3 & 2 & 1\end{array}$ 


\section{Contents}

Introduction

Part I

The Founding Era

Chapter 1: Cold War and Codetermination

Chapter 2: An Alliance for a New Westpolitik

\section{Part II}

\section{The Détente Era}

Chapter 3: Détente and Democracy 61

$\begin{array}{ll}\text { Chapter 4: An Alliance for a New Ostpolitik } & 79\end{array}$

\section{Part III}

\section{Unification}

Chapter 5: The Two Dimensions of Deutschlandpolitik

Conclusion

Notes

Selected Bibliography

Index 


\section{Acknowledgments}

For their support on this project, I am indebted to many individuals and institutions. Foremost, I would like to thank my family and friends for their patience and encouragement. Peter Katzenstein, Jonas Pontusson, Martin Shefter, and Sydney Tarrow all made insightful comments during the early stages of this project at Cornell University. As a fellow at the Berlin Program for Advanced German and European Studies, I had the opportunity to witness Germany's unification firsthand. I am indebted to the directors of the Berlin Program, Monika Medick-Krakau and Ingeborg Mehser, for their support during and after my fellowship there. As a Research Associate at the Center for German and European Studies at Georgetown University, I researched and wrote the third case study. I would also like to thank Connecticut College for providing me with generous research support. While a fellow of the Friedrich-Ebert-Stiftung in 1997, I developed a better understanding of politics in Germany since unification.

I would like to thank Mary McKenzie, Michael Harvey, Greg Colman, my readers at St. Martin's Press, and above all Robert Kahn, who carefully read and commented on the manuscript in its entirety. For his many hours of hard work at Yale's Sterling Memorial Library, I would like to thank Jens Kreinath. Finally, I am indebted to Anita Allen for secretarial assistance. 